\title{
Environmental Assessment of Groundwater Quality for Irrigation Purposes: A Case Study Of Hillah City In Iraq
}

\author{
Zaid Abed Al-Ridah ${ }^{1}$, Ahmed Samir Naje ${ }^{1 *}$, Diaa Fliah Hassan ${ }^{1}$ and Hussein Ali \\ Mahdi Al-Zubaid ${ }^{2}$ \\ ${ }^{1}$ College of Water Resources Engineering, Al-Qasim Green University, Babylon, Iraq \\ ${ }^{2}$ Department of Environmental Engineering, College of Engineering, University of Babylon, Babylon, Iraq
}

\begin{abstract}
This study was conducted to evaluate the groundwater quality of wells located around the Hillah city of Iraq, for the purposes of determining its suitability as water for agricultural irrigation, according to the Irrigation Water Quality Index (IWQI). The number of wells that are being investigated was 24 . The spatial distribution of water quality parameters was investigated using ArcGIS software. Ten parameters were established for the dry and wet seasons of 2018 and 2019, which include $\mathrm{pH}$, electric conductivity (EC), total dissolved solids (TDS), calcium, potassium, magnesium, bicarbonate, sodium, chloride and sulfuric. The results showed that all $\mathrm{pH}$ and sodium absorption ratio values were within the allowable limits. About $69 \%$, and $75 \%$ electric conductivity, total dissolved solids, values respectively were higher than the allowable limits. Most values of positive and negative ions were higher than the allowable limits. In 2018, the water quality of (4\%) of wells number was classified as moderate restriction and approximately $96 \%$ was poor quality in dry season, while the IWQI was enhanced in the wet season. In 2019, the quality of water was dropped as most of the water quality was classified as severe restriction and few in the high restriction for the dry season. These values were increased in the wet season due to the freshwater dilution effect. Water

ARTICLE INFO

Article history:

Received: 08 December 2020

Accepted: 01 April 2021

Published: 31 July 2021

DOI: https://doi.org/10.47836/pjst.29.3.10 quality index show that a large percentage of the wells have poor water quality leads to severe restriction for irrigation requirements and need relatively high permeability soils and salt-resistant plants.
\end{abstract}

E-mail addresses:

zaidalmnsory@yahoo.com (Zaid Abed Al-Ridah)

ahmednamesamir@yahoo.com (Ahmed Samir Naje)

diaafliah@wrec.uoqasim.edu.iq (Diaa Fliah Hassan)

alzubaidih10@gmail.com (Hussein Ali Mahdi Al-Zubaid)

* Corresponding author

Keywords: Groundwater, irrigation, spatial distribution, water quality index, wells 


\section{INTRODUCTION}

Water is an important source of life for human societies and other living creatures (AlRidah et al., 2020). Geographically, Iraq is one of the Middle Eastern countries that suffer from a semi-arid climate. The main source of water in Iraq is the Tigris and Euphrates rivers, whose water sources are from Turkey. Recently, and specifically since 1990, Turkey started construction of the GAP "Southeastern Anatolia Project "project, which consists of 24 dams and led to a significant decrease in the water supply to Iraq (Al-Mohammed \& Mutasher, 2013). Therefore, it is necessary to search for an additional source that reduces the lack of water revenues for the country. Groundwater is one of the most important other alternative water sources that are used for various purposes, including irrigation, drinking, and industry (Abdullah et al., 2015). When groundwater gets polluted, it becomes difficult to get rid of pollution even when it is stopped from its source. Therefore, assessing groundwater quality for different purposes is necessary. The Water Quality Index (WQI) is used in terms of numbers to assess the quality of water to be used for any purpose (Mahmood et al., 2013). The Water Quality Index (WQI) is an effective way to classify, manage, and define groundwater quality as a single parameter. It measures water quality for multiple purposes (drinking, irrigation, and industries) by converting a set of water quality variables into a single value to determine the water quality in general (Boateng et al., 2016). WQI is a mathematical model used to convert water quality variables into a single value that represents the water quality level for a specific place and time (Gidey, 2018). The city of Hilla is characterized as an agricultural city with a high density, which requires large quantities of irrigation water. These quantities are mostly prepared from the Euphrates river and its branches in the city. Also, due to the low water imports, as mentioned above, groundwater is used in different places of the region to supply water to plants for agricultural lands around the city or for public and private gardens within the city. Therefore, the objective of current study is to investigate the suitability of groundwater in the region for the purpose of irrigation requirements using the irrigation water quality index (IWQI) and to make a spatial distribution of water quality elements to obtain a map of the quality of groundwater in the Hilla city.

\section{MATERIALS AND METHOD}

\section{Area of the Study}

The city of Hillah is in the center of Iraq. The main source of irrigation and drinking water is the Euphrates River and its multiple branches. About 24 shallow wells in the area were dug in unconfined aquifer as shown in detail in Table 1 and as shown by its spatial distribution according to Figure 1 . The studied area covers about 80 by $40 \mathrm{Km}$ and its climate is characterized by being hot, dry in summer, cool and less rainy in winter (Al-Dabbas \& Al-Ali, 2016). Its soil is alluvial clay, sandy soils and containing on organic matter with 
Environmental Assessment of Well Water Quality for Irrigation

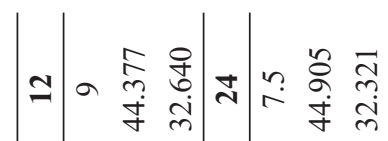

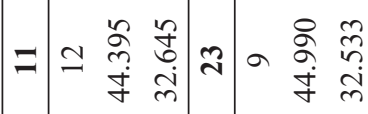

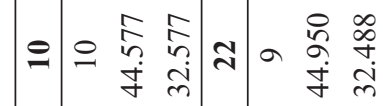

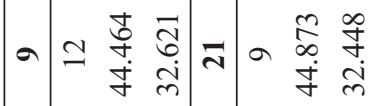

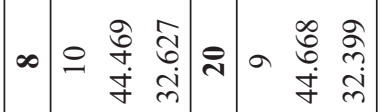

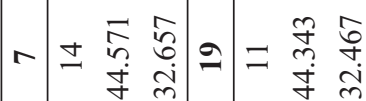

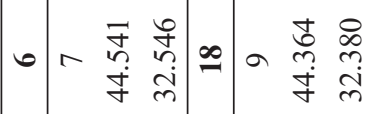

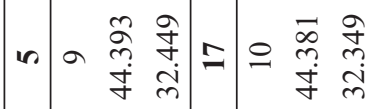

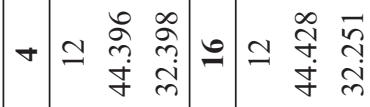

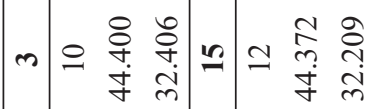

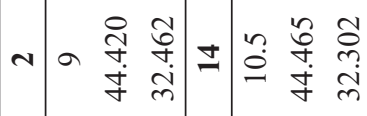

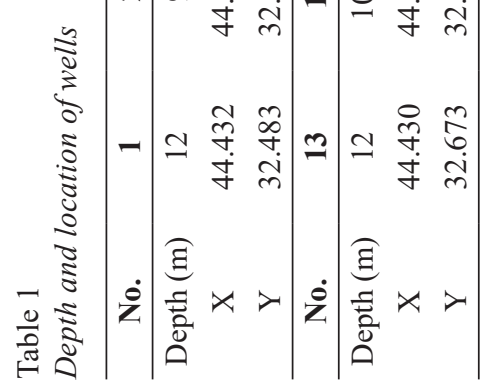
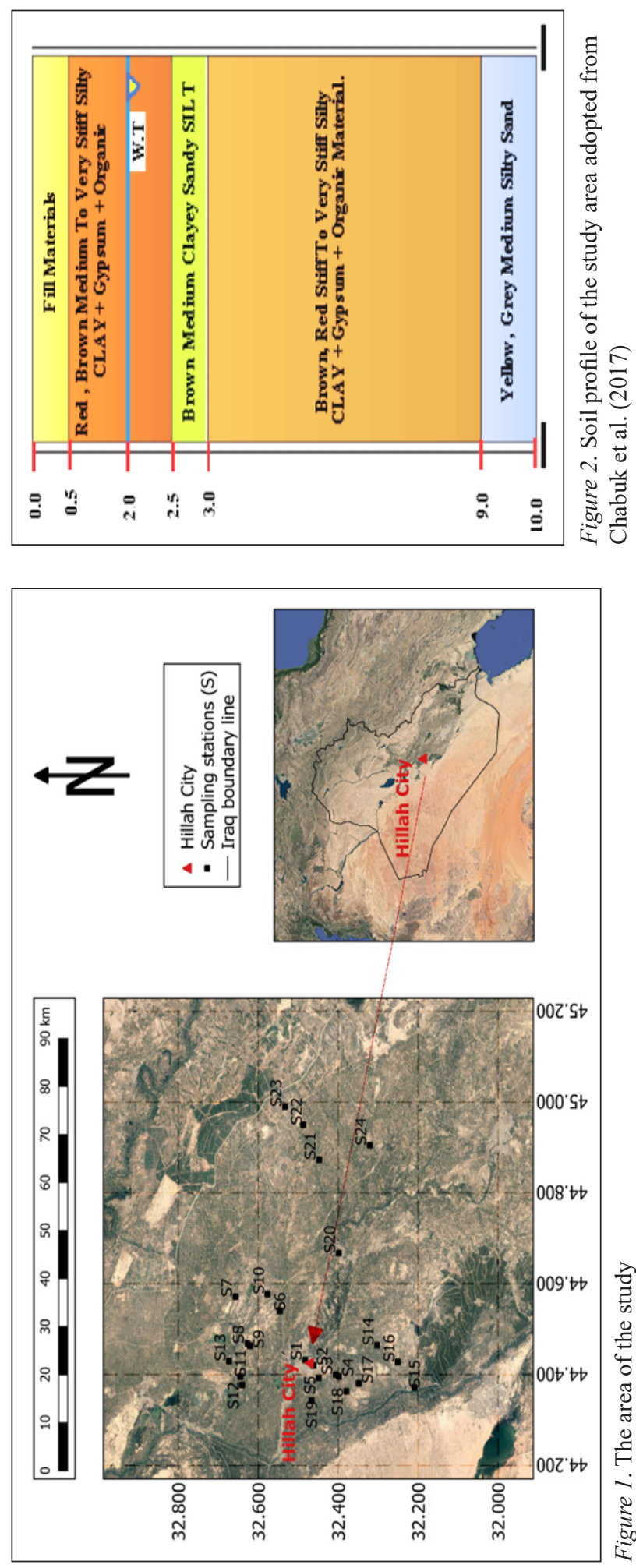
soft and weak cohesion properties due to relatively high levels of groundwater in most of its regions as shown in Figure 2 (Al-Khaqani, 2006; Al-Zubaydi et al., 2016; Chabuk et al., 2017). Tests were conducted for the water produced from it for the dry seasons (July) and wet seasons (January) and for two consecutive years (2018-2019). The study includes ten water quality parameters which are $\mathrm{pH}$, Total Dissolved Solids (TDS), Electric Conductivity (EC), Calcium $\left(\mathrm{Ca}^{2+}\right)$, Potassium $\left(\mathrm{K}^{+}\right)$, Magnesium $\left(\mathrm{Mg}^{2+}\right)$, Bicarbonate $\left(\mathrm{HCO}_{3}^{-}\right)$, Sodium $\left(\mathrm{Na}^{+}\right)$, Chloride $\left(\mathrm{Cl}^{-}\right)$, Sulfuric $\left(\mathrm{SO}_{4}^{-}\right)$. The standard methods are used in the laboratory to test water quality parameters and to calculate the water quality index for the region.

\section{Irrigation Water Quality Index (IWQI)}

To assess the quality of groundwater in Hillah city to determine their suitability for irrigation purposes, IWQI was used (Meireles et al., 2010). In this method and for the purpose of calculating the relative weight, the estimated values for each parameter (which should be used) must be from the irrigation water quality data according to the University of California Consultation Committee (UCCC), Ayers and Westcot (1999), and Abbasnia et al. (2018).

The first step to build a model is to determine the influencing and controlling elements of the water quality used for irrigation. The elements $\left(\mathrm{EC}, \mathrm{Na}+, \mathrm{Cl}\right.$, and $\mathrm{HCO}_{3}$ ), as well as the sodium absorption ratio SAR, were considered because they had the greatest influence on IWQI, as stated in Meireles et al. (2010). The second step is to determine the measurement values for the water quality $\left(\mathrm{q}_{\mathrm{i}}\right)$ based on Table 2 according to Ayers and Westcot (1985), the values of (qi) are calculated from Equation 1:

$$
q_{i}=q_{\max }-\left[\frac{\left(x_{i j}-x_{i n f}\right)}{x_{a m p}} \times q_{i m a p}\right]
$$

Where:

qi:limiting values parameter for quality measurement.

$\mathrm{q}_{\text {imax }}$ : maximum value of qi for the class.

$\mathrm{x}_{\mathrm{ij}}$ : observed parameter value.

$\mathrm{x}_{\text {inf: }}$ : equivalent value to the lower limit of the class to which the parameter belongs.

$\mathrm{q}_{\text {iamp: class amplitude. }}$

$\mathrm{x}_{\mathrm{amp}}$ : class amplitude to which the parameter belongs.

For calculating the value ( $\mathrm{x}_{\mathrm{amp}}$ ) of the last class in Table 2 for each element, the upper limit was considered equal to the highest value calculated in the analysis of water quality data. The cumulative weight $\left(\mathrm{w}_{\mathrm{i}}\right)$ is calculated according to Majeed et al. (2016) from Table 3 where the values of $\left(\mathrm{w}_{\mathrm{i}}\right)$ are normalized and therefore when combined they are equal to 1 .

The water quality index is calculated from the following Equation 2:

$$
\operatorname{IWQI}=\sum_{\mathrm{i}=1}^{\mathrm{n}} \mathrm{q}_{\mathrm{i}} \mathrm{w}_{\mathrm{i}}
$$


Where (IWQI) is the irrigation water quality index and it is a non-dimensional value between 0 and 100. For any sample, the higher value of (IWQI) gives the best quality of water according to Table 4 (Bernardo, 1995; Holanda \& Amorim, 1997).

Table 2

Water quality measurement (qi) parameter limiting value adopted from Ayers \& Westcot (1985)

\begin{tabular}{cccccc}
\hline $\mathbf{q}_{\mathbf{i}}$ & $\begin{array}{c}\mathbf{E C} \\
(\boldsymbol{\mu \mathbf { s }} / \mathbf{c m})\end{array}$ & $\begin{array}{c}\mathbf{S A R} \\
(\mathbf{m e q} / \mathbf{L})^{\mathbf{0} .5}\end{array}$ & $\begin{array}{c}\mathbf{N a}^{+} \\
(\mathbf{m e q} / \mathbf{L})\end{array}$ & $\begin{array}{c}\mathbf{C l}^{-} \\
(\mathbf{m e q} / \mathbf{l})\end{array}$ & $\begin{array}{c}\mathbf{H C O}_{3}^{-} \\
(\mathbf{m e q} / \mathbf{l})\end{array}$ \\
\hline & & & & & \\
$85-100$ & $200 \leq \mathrm{EC}<750$ & $\mathrm{SAR}<3$ & $2 \leq \mathrm{Na}<3$ & $\mathrm{Cl}<4$ & $1 \leq \mathrm{HCO} 3<1.5$ \\
$60-85$ & $750 \leq \mathrm{EC}<1500$ & $3 \leq \mathrm{SAR}<6$ & $3 \leq \mathrm{Na}<6$ & $4 \leq \mathrm{Cl}<7$ & $1.5 \leq \mathrm{HCO} 3<4.5$ \\
$35-60$ & $1500 \leq \mathrm{EC}<3000$ & $6 \leq \mathrm{SAR}<12$ & $6 \leq \mathrm{Na}<9$ & $7 \leq \mathrm{Cl}<10$ & $4.5 \leq \mathrm{HCO} 3<8.5$ \\
$0-35$ & $\mathrm{EC}<200$ or $\mathrm{EC} \geq 3000$ & $\mathrm{SAR} \geq 12$ & $\mathrm{Na}<2$ or $\mathrm{Na} \geq 9$ & $\mathrm{Cl} \geq 10$ & $\mathrm{HCO} 3<1$ or $\mathrm{HCO} 3 \geq 8.5$ \\
\hline
\end{tabular}

Table 3

IWQI parameters weights $\left(w_{i}\right)$ adopted from

Majeed et al. (2010)

\begin{tabular}{lc}
\hline Parameters & $\mathbf{w}_{\mathbf{i}}$ \\
\hline $\mathrm{EC}$ & 0.211 \\
$\mathrm{Na}^{+}$ & 0.204 \\
$\mathrm{HCO}_{3}^{-}$ & 0.202 \\
$\mathrm{Cl}^{-}$ & 0.194 \\
$\mathrm{SAR}$ & 0.189 \\
Total & 1 \\
\hline
\end{tabular}

Table 4

Irrigation water quality index features adopted from Bernardo (1995) and Holanda and Amorim (1997).

\begin{tabular}{|c|c|c|c|}
\hline \multirow{2}{*}{ WQI } & \multirow{2}{*}{$\begin{array}{l}\text { Water use } \\
\text { restrictions }\end{array}$} & \multicolumn{2}{|c|}{ Recommendation } \\
\hline & & Soil & Plant \\
\hline $85-100$ & $\begin{array}{l}\text { No } \\
\text { restriction } \\
\quad(\mathrm{NR})\end{array}$ & $\begin{array}{l}\text { It can be used for most soils with a low } \\
\text { potential to cause salinity and sodium } \\
\text { problems, and filtration is recommended } \\
\text { within irrigation practices, except for soils } \\
\text { with very low permeability. }\end{array}$ & $\begin{array}{l}\text { There are no toxic risks for most } \\
\text { plants }\end{array}$ \\
\hline $70-85$ & $\begin{array}{l}\text { Low } \\
\text { restriction } \\
\quad(\mathrm{LR})\end{array}$ & $\begin{array}{l}\text { It is recommended for use on irrigated soils } \\
\text { with light texture or moderate permeability, } \\
\text { and salt filtering is recommended. Soil } \\
\text { sodium may occur in soils with heavy } \\
\text { texture, and it is recommended to avoid their } \\
\text { use on soils with high clay levels of } 2: 1 \text {. }\end{array}$ & $\begin{array}{l}\text { Avoid plants that are sensitive to } \\
\text { salt }\end{array}$ \\
\hline $55-70$ & $\begin{array}{l}\text { Moderate } \\
\text { restriction } \\
(\mathrm{MR})\end{array}$ & $\begin{array}{l}\text { It can be used on soils with medium to } \\
\text { high permeability values, while suggesting } \\
\text { moderate salt leaching. }\end{array}$ & $\begin{array}{l}\text { Plants with moderate salt tolerance } \\
\text { can be grown. }\end{array}$ \\
\hline
\end{tabular}


Table 4 (continue)

\begin{tabular}{|c|c|c|c|}
\hline \multirow{2}{*}{ WQI } & \multirow{2}{*}{$\begin{array}{l}\text { Water use } \\
\text { restrictions }\end{array}$} & \multicolumn{2}{|c|}{ Recommendation } \\
\hline & & Soil & Plant \\
\hline $40-55$ & $\begin{array}{l}\text { High } \\
\text { restriction } \\
(\mathrm{HR})\end{array}$ & $\begin{array}{l}\text { It can be used on soils with high permeability } \\
\text { without compact layers. A high frequency } \\
\text { irrigation schedule should be adopted for } \\
\text { water with an EC higher than } 2.000 \mathrm{dS} \mathrm{m}-1 \\
\text { and SAR above } 7.0 \text {. }\end{array}$ & $\begin{array}{l}\text { It should be used to irrigate plants } \\
\text { with medium to high salt tolerance } \\
\text { with special salinity control } \\
\text { practices, with the exception of } \\
\text { water with low values of sodium, } \\
\text { chloride, and HCO3. }\end{array}$ \\
\hline $0-40$ & $\begin{array}{l}\text { Severe } \\
\text { restriction } \\
\quad(\mathrm{SR})\end{array}$ & $\begin{array}{l}\text { Its use for irrigation should be avoided under } \\
\text { normal conditions. In special cases, they } \\
\text { may be used occasionally. Water with low } \\
\text { levels of salt and a high specific absorption } \\
\text { rate requires the application of gypsum. In } \\
\text { soils with high salt content, the soil should } \\
\text { be of high permeability, and excess water } \\
\text { should be used to avoid salt accumulation. }\end{array}$ & $\begin{array}{l}\text { Only plants with high salt tolerance, } \\
\text { except for water with very low } \\
\text { values of } \mathrm{Na}, \mathrm{Cl} \text { and } \mathrm{HCO} 3\end{array}$ \\
\hline
\end{tabular}

Note: $\mathrm{SR}$ - severe restriction; HR - high restriction; MR - moderate restriction; LR - no restriction.

\section{RESULTS AND DISCUSSION}

\section{Water Quality Parameters and Spatial Distribution}

The statistical parameters represented by the mean and standard deviation (SD) of the ten water quality parameters are presented in Table 5. It is noted that the mean rate in the dry season of the concentration of most water quality data exceeds the mean in the wet season for the same year due to the dilution process during high levels of water in the wet season (Hassan et al., 2017). Using the program (ArcGIS) and by taking advantage of interpolation and drawing the spatial distribution on the map of the region under study for the average concentration of the ten water quality parameters, which includes the locations of wells numbered from 1 to 24 as shown in Figures 3 and 4.

pH Effect. pH is affected by dissolved salts in groundwater such as carbonates, bicarbonate, silicates, fluorides, and other salts in the dissociated form. High values $(\mathrm{pH})$ indicate the presence of sodium and low values reflect the presence of free acids in water (Kushwah et al., 2012). The spatial distribution shows that the values of the $(\mathrm{pH})$ are closely related and rise in the southern part (well 14 and 20) and the northwestern (well 11, 12, and 19). It decreases in the eastern part (well 20,22 and 24) and the northern (well 10 and 7) on the map. The amount of the value of $(\mathrm{pH})$ ranges from 7.01 to 7.93 with an average value of 7.32. These values are all within the parameters of the Food and Agriculture Organization (FAO) (6.5-8.5) (Ayers \& Westcot, 1999).

Electrical Conductivity (EC) Effect. EC is a good indicator for measuring the amount of dissolved solids in groundwater; therefore, it is used to detect pollutants in water. Through 
measuring electrical conductivity, one can gain the concentration of salts and mineral substances in groundwater (Deshmukh, 2013). Noting the spatial distribution of (EC), their values are high in the eastern parts (wells 20, 21, 22, and 24), the far west (wells 12, 16 and 19) and low in the central western part (wells 1, 6, 7, 8, 9, and 10) of the map. It is noted that the values of electrical conductivity were confined between $1518 \mu \mathrm{s} / \mathrm{cm}$ ) and $10190 \mu \mathrm{s} / \mathrm{cm}$ ) for the dry season of the year 2018. According to the specifications of FAO, (31\%) of all groundwater samples are moderate salinity $(700-3000 \mu \mathrm{s} / \mathrm{cm})$ and the rest are very salty (above $3000 \mu \mathrm{s} / \mathrm{cm}$ ).

Total Dissolved Solids (TDS) Effect. Dissolved solids consist of water leaching through the soil, dissolved limestone, gypsum, rocks exposed to erosion and other salts. The flow of water through the subsurface and geological formations carries with it many salts and dissolved ions, thus changing the quality of the groundwater (Jain et al., 1997). Increasing concentrations of dissolved salts such as sodium, magnesium, chlorides, sulfates, and calcium carbonate in addition to human activities will contribute to increase the amount of salinity in the groundwater and thus increasing the amount of TDS (Salama et al., 1999). Through the spatial distribution of (TDS), it is noted that its values are high in the eastern parts (wells 20,21, 22, and 24), the far west (wells 12, 16, and 19). Yet, it is low in the central western part (wells 1, 6, 7, 8, 9, and 10). The lowest value for (TDS) is (1220 mg $/ \mathrm{L})$ at the highest value $(8021 \mathrm{mg} / \mathrm{L})$ in the dry season of 2018 . The food and agriculture organization has determined the values of (TDS) as causing a slight to moderate restriction in the use of irrigation water (Slight to Moderate of Restriction on use if its value is between $(450-2000 \mathrm{mg} / \mathrm{L})$ and severe restriction if it increases above this limit. It was noted that $25 \%$ of the measured samples with TDS values were described as slight to moderate restriction and the rest were highly restricted water in use.

Cation $\left(\mathrm{K}^{2+}, \mathrm{Na}^{+}, \mathrm{Mg}^{2+}\right.$ and $\mathrm{Ca}^{2+}$ ) Effect. The most important sources of cation in groundwater are weathering processes of soil and rocks, whether sedimentary or igneous, and human activities. They reach groundwater by filtering water through the soil (Sravanthi \& Sudarshan, 1998; Basha et al., 2010; Lateef, 2011). Mostly, the spatial distribution shows that the values of cations on the map are high in the southeast and northwestern part and decrease in the eastern and northern part on the map. Through Table 5, the lowest values were $\left(K=0.975 \mathrm{mg} / \mathrm{L}\right.$ in the dry season of $2018, \mathrm{Na}^{+}=68 \mathrm{mg} / \mathrm{L}$ for the wet season of the same year, $\mathrm{Mg}^{2+}=5.16 \mathrm{mg} / \mathrm{L}$ for the wet season of 2019 and $\mathrm{Ca}^{2+}=17.6 \mathrm{mg} / \mathrm{L}$ for the wet season of 2019). The highest values were $\left(\mathrm{K}^{2+}=124.8 \mathrm{mg} / \mathrm{L}\right.$ is in the dry season of $2018, \mathrm{Na}^{+}=736 \mathrm{mg} / \mathrm{L}$, for the wet season for the same year, $\mathrm{Mg}^{2+}=159 \mathrm{mg} / \mathrm{L}$ for the wet season for 2019 and $\mathrm{Ca}^{2+}=366 \mathrm{mg} / \mathrm{L}$ for the dry season of the same year). The acceptable limitations for positive elements are $\left(\mathrm{K}^{2+}<10 \mathrm{mg} / \mathrm{L}, \mathrm{Na}^{+}<50 \mathrm{mg} / \mathrm{L}, \mathrm{Mg}^{2+}<24 \mathrm{mg} / \mathrm{L}, \mathrm{Ca}^{2}\right.$ 
$+<120 \mathrm{mg} / \mathrm{L}$ ). For four seasons, the results of the groundwater analysis showed that $65 \%$, $100 \%, 90 \%$ and $60 \%$ of the observed values for $\mathrm{K}^{2+}, \mathrm{Na}^{+}, \mathrm{Mg}^{2+}$ and $\mathrm{Ca}^{2+}$ respectively, are higher than the desired limits.

Anion $\left(\mathrm{Cl}^{-}, \mathrm{SO}_{4}{ }^{2-}, \mathrm{HCO}^{3-}\right)$ Effect. The important source of chloride salts $\left(\mathrm{Cl}^{-}\right)$in groundwater is weathering processes for rocks and soil and are transported to groundwater by filtration. While sulfates $\left(\mathrm{SO}_{4}{ }^{2-}\right)$, groundwater reaches it through weathering processes of (sulphide-bearing) or soil can be another source for sulfates. Further, evaporation deposits can also be a source for sulfates. Another important source is airborne pollutants containing sulfur oxides and converts them to sulfuric acid during rain fall to filter into the soil (Singh et al., 2012; Mallick, 2017). Having bicarbonate ions $\left(\mathrm{HCO}_{3}^{-}\right)$in groundwater is associated with the presence of magnesium and calcium ions or is released from rocks, soil and the disintegration of the gypsum or the presence of carbon dioxide and calcium carbonate water that interact in the presence of water to produce $\left(\mathrm{HCO}_{3}{ }^{-}\right)$(Ravikumar \& Somashekar, 2015; Al-Qawati et al., 2018). In general, the spatial distribution of anions values on the map shows that they are high in the southern part and somewhat western part and low in the northern part excepting the wells 12 and 13 on the map. The lowest value was $\left(\mathrm{Cl}^{-}=157.85 \mathrm{mg} / \mathrm{L}\right.$ in the dry season, $\mathrm{SO}_{4}{ }^{2-}=96 \mathrm{mg} / \mathrm{L}$, for the wet season, and $\mathrm{HCO}_{3}{ }^{-}=$ $90 \mathrm{mg} / \mathrm{L}$ for the wet season) for the year 2018. As for the highest value of $\mathrm{Cl}^{-}=1200 \mathrm{mg} / \mathrm{L}$ in the dry season of $2018, \mathrm{SO}_{4}{ }^{2-}=1412 \mathrm{mg} / \mathrm{L}$, for the dry season of 2019 , and $\mathrm{HCO}_{3}{ }^{-}=$ $955 \mathrm{mg} / \mathrm{L}$ for the season dry for the year 2018. Allowed values for negative elements are $\left(\mathrm{Cl}^{-}<140 \mathrm{mg} / \mathrm{L}, \mathrm{SO}^{2-}<400 \mathrm{mg} / \mathrm{L}, \mathrm{HCO}_{3}{ }^{-}<120 \mathrm{mg} / \mathrm{L}\right)$. For four seasons, the results of the groundwater analysis showed that $100 \%, 75 \%$ and $97 \%$ of the values of $\mathrm{Cl}^{-}, \mathrm{SO}_{4}{ }^{2-}$ and $\mathrm{HCO}_{3}^{-}$, respectively, were higher than the permissible values.

Sodium Absorption Ratio (SAR). SAR is an important component for assessing the validity of irrigation water. The higher the sodium concentration in irrigation water is the more sodium absorption will increase. This reduces the validity of irrigation water. The effect of irrigation water on soil permeability to water depends on the interference between the flocculating effects of specific conductance and the diffusion effect of sodium. If the specific conductance is high, this increases the soil's tolerance to water with a high SAR (Bhat et al., 2018). The distribution of the value of (SAR) spatially distributed scattered over the directions of the map may seem high for wells $(4,10,12,16$, and 22), and low for other wells $(7,14,17,18$, and 21). The FAO organization has defined different ranges of the value of (SAR). The higher the electrical conductivity is the greater the negative impact of the (SAR) on the water viability for irrigation purposes. The maximum value was in the dry season of the year 2018 and was ( $\mathrm{SAR}=5.27$ ). The lowest value (SAR $=$ 1.49) was in the wet season of 2019 and is somewhat close to the corresponding value in 
the year 2018 (SAR = 1.51). For SAR values between (0-3 and 3-6), the values of (EC) were $(<700,700-2000$ and $>2000 \mu \mathrm{s} / \mathrm{cm})$ leading to problems ranging from zero-effect, medium to high-impact, respectively.
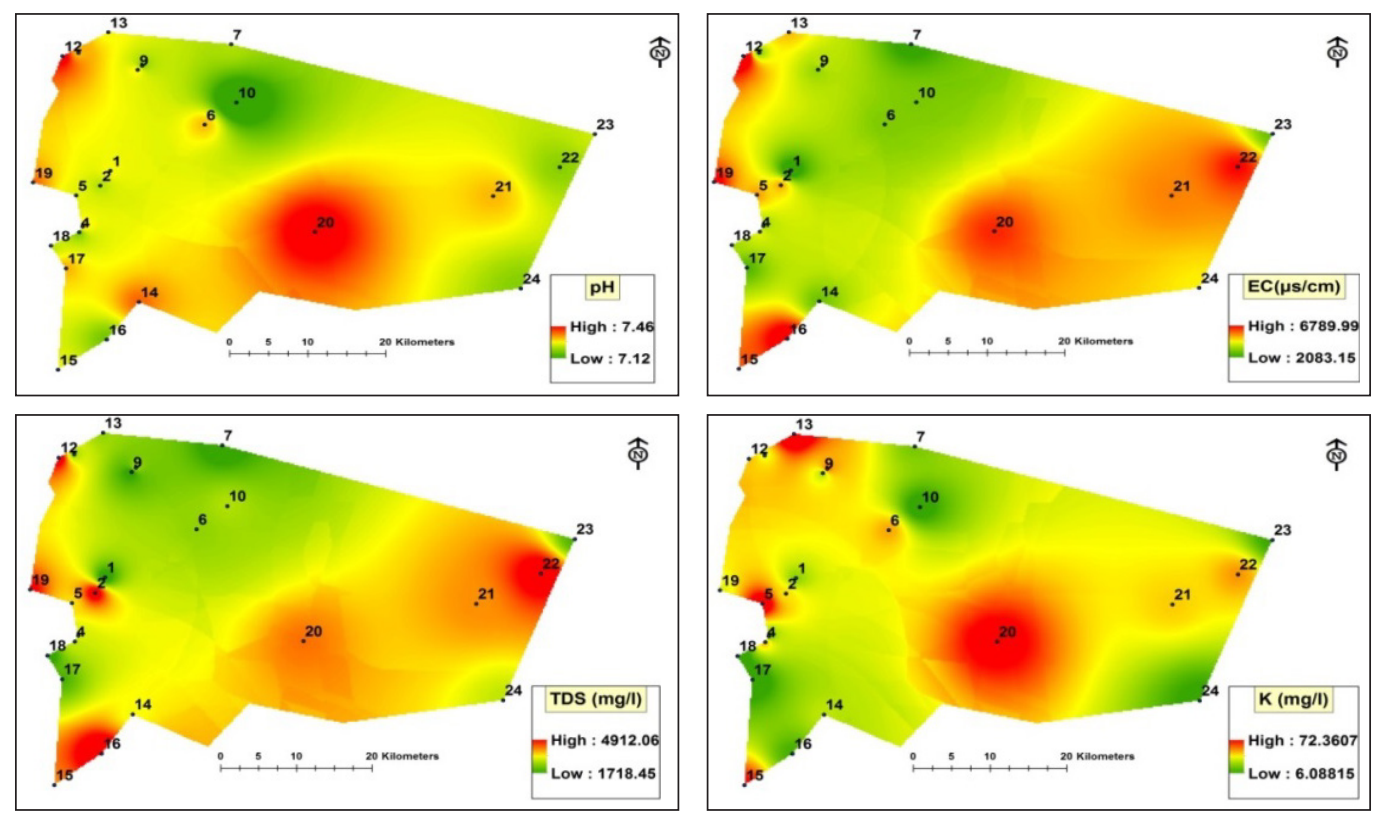

Figure 3. Spatial distribution of average of $\mathrm{pH}, \mathrm{EC}$, TDS and $\mathrm{K}^{+}$in the studied area
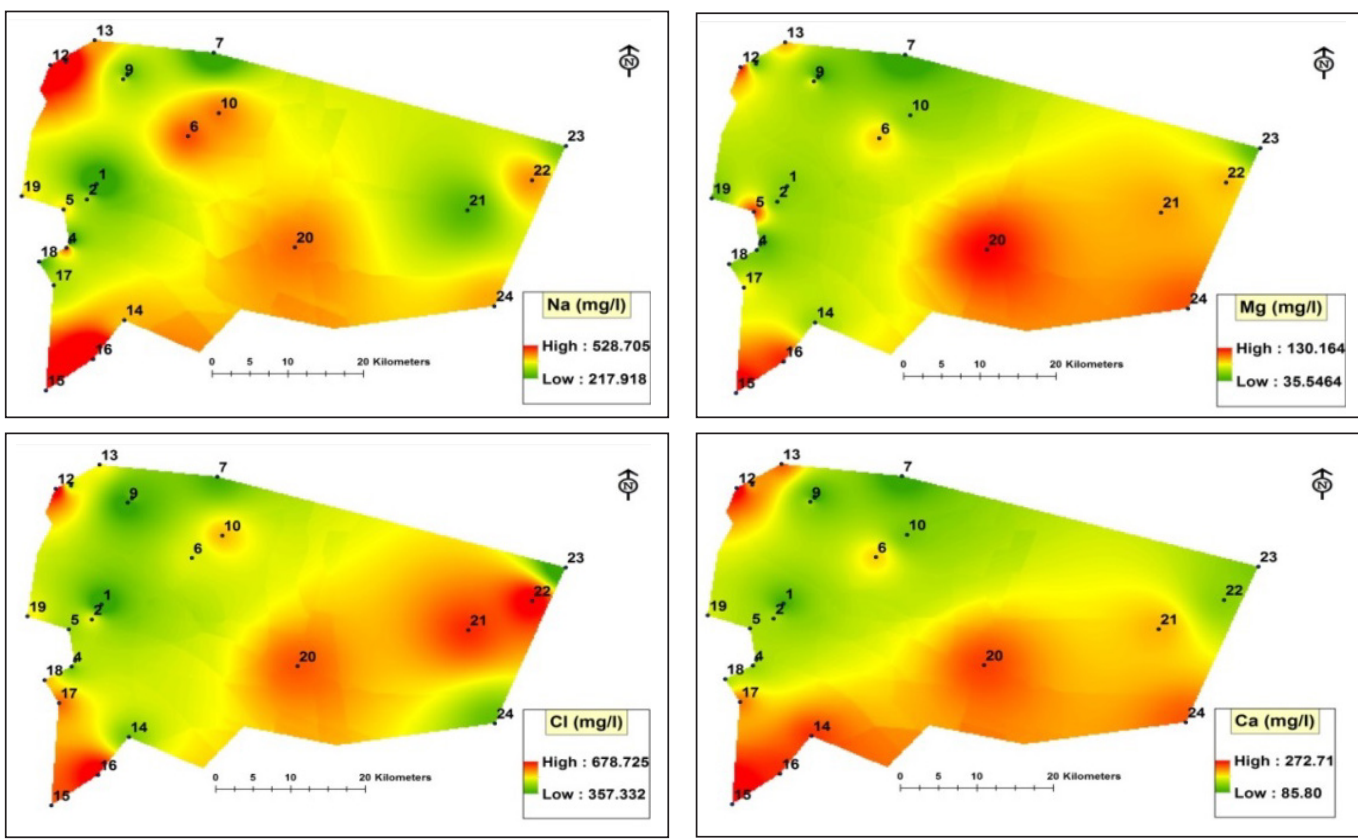

Figure 4. Spatial distribution of average $\mathrm{Na}^{+}, \mathrm{Mg}^{2+}, \mathrm{Ca}^{2+}, \mathrm{Cl}, \mathrm{SO} 4, \mathrm{HCO}_{3}^{-}$and $\mathrm{SAR}$ in the studied area 


\section{Irrigation Water Quality Index (IWQI)}

Based on Equations 1 and 2 as well as Table 2 and 3, the Water Quality Index (IWQI) for the dry and wet seasons of 2018 and 2019 for all wells was calculated. The values of (IWQI) are shown in Figure 5. Figure 5 shows the changes in the values of (IWQI) over the four seasons of most wells where the highest values of (IWQI) were in the wet season of 2018 and the lowest values in the dry season for the same year. The annual rate of (IWQI) values were calculated for each season separately and as in Table 6. Table 6 shows that the water quality in the wet season is of higher value (IWQI) than most of the dry season for most wells. In general, the high-water levels in the wet season in the Hilla River and the branching irrigation canals raise the water level (Al-Amar, 2015). Consequently, this reduces the concentrations of water quality elements due to dilution which leads to high values of (IWQI) and improvement of groundwater quality accordingly. By comparing the values of (IWQI) with the determinants in Table 4, the quality of the well water can be classified into several classes, as shown in Table 7. For example, (67\%) of the wells in the dry season of 2018 can be classified under the category (SR) and (29\%) and (4\%) of the

Table 6

Wells IWQI of each season and year

\begin{tabular}{|c|c|c|c|c|c|c|c|}
\hline \multirow{2}{*}{$\begin{array}{l}\text { Well } \\
\text { No. }\end{array}$} & \multicolumn{2}{|c|}{ Mean of IWQI } & \multirow{2}{*}{$\begin{array}{c}\text { Overall mean of } \\
\text { IWQI }\end{array}$} & \multirow{2}{*}{$\begin{array}{l}\text { Well } \\
\text { No. }\end{array}$} & \multicolumn{2}{|c|}{ Mean of IWQI } & \multirow{2}{*}{$\begin{array}{c}\text { Overall } \\
\text { mean of IWQI }\end{array}$} \\
\hline & Dry & Wet & & & Dry & Wet & \\
\hline 1 & 43.08 & 58.81 & 50.95 & 13 & 31.25 & 53.20 & 42.22 \\
\hline 2 & 32.58 & 51.89 & 42.24 & 14 & 45.93 & 44.66 & 45.29 \\
\hline 3 & 39.55 & 56.23 & 47.89 & 15 & 29.60 & 42.31 & 35.95 \\
\hline 4 & 30.58 & 46.52 & 38.55 & 16 & 26.77 & 34.86 & 30.81 \\
\hline 5 & 35.46 & 39.79 & 37.62 & 17 & 46.68 & 43.45 & 45.07 \\
\hline 6 & 40.16 & 41.05 & 40.60 & 18 & 51.87 & 48.93 & 50.40 \\
\hline 7 & 41.96 & 66.72 & 54.34 & 19 & 34.28 & 44.15 & 39.21 \\
\hline 8 & 36.32 & 49.27 & 42.80 & 20 & 26.94 & 48.63 & 37.78 \\
\hline 9 & 47.66 & 56.97 & 52.31 & 21 & 32.17 & 47.82 & 40.00 \\
\hline 10 & 35.49 & 45.69 & 40.59 & 22 & 26.18 & 43.21 & 34.70 \\
\hline 11 & 40.45 & 40.53 & 40.49 & 23 & 37.38 & 63.16 & 50.27 \\
\hline 12 & 25.50 & 36.53 & 31.01 & 24 & 35.29 & 39.08 & 37.19 \\
\hline
\end{tabular}

Table 7

IWQI classification of groundwater quality

\begin{tabular}{|c|c|c|c|c|c|}
\hline \multirow{2}{*}{ IWQI } & \multirow{2}{*}{$\begin{array}{c}\text { Water Use } \\
\text { Restrictions }\end{array}$} & \multicolumn{2}{|c|}{2018} & \multicolumn{2}{|c|}{2019} \\
\hline & & Dry & Wet & Dry & Wet \\
\hline $0-40$ & SR & $67 \%$ & $37.5 \%$ & $62.5 \%$ & $41.7 \%$ \\
\hline $40-55$ & HR & $29 \%$ & $33.3 \%$ & $37.5 \%$ & $45.8 \%$ \\
\hline $55-70$ & MR & $4 \%$ & $8.3 \%$ & ........ & $12.5 \%$ \\
\hline $70-85$ & LR & $\ldots \ldots$ & $20.8 \%$ & $\ldots .$. & $\ldots \ldots$ \\
\hline
\end{tabular}


wells under the category (HR) and (MR), respectively, and so on. Through the schedule, we can say that these wells in the best conditions suffer from restrictions in use for irrigation purposes and the problem is more than that in the dry season.

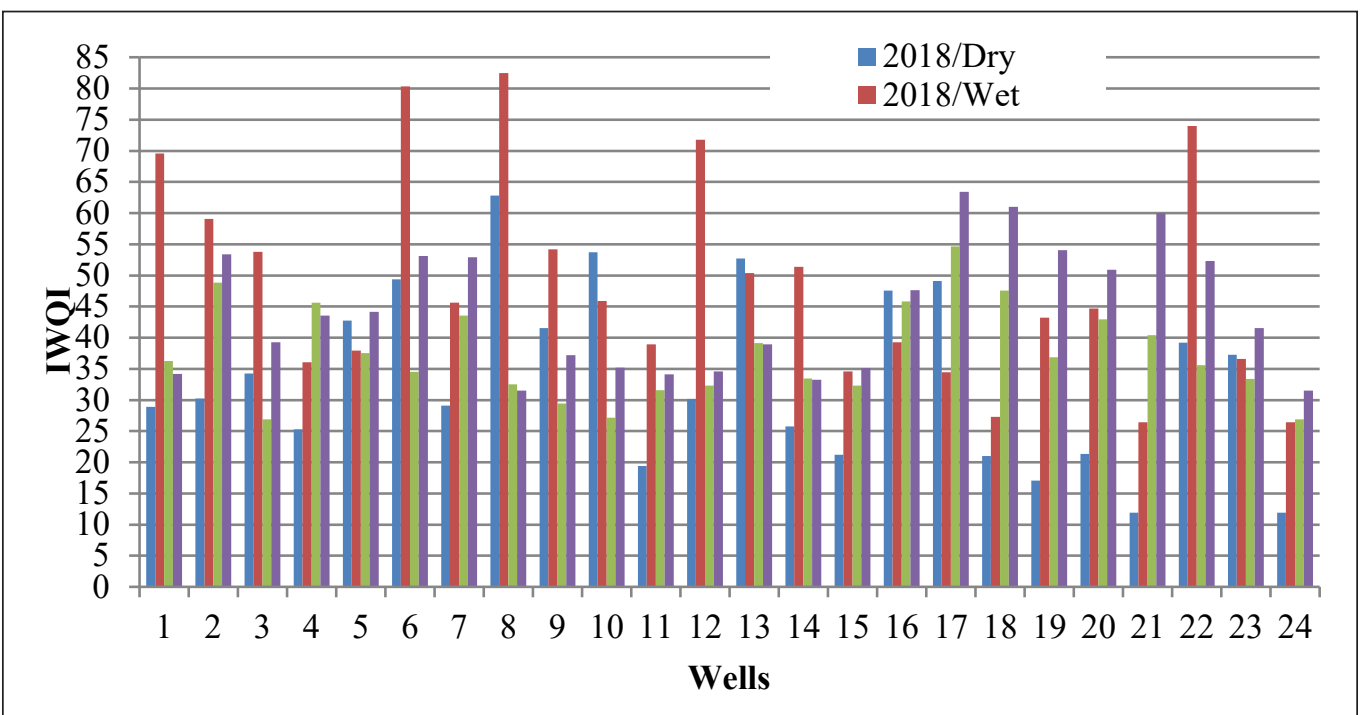

Figure 5. The four seasonal variation at each well is shown starting with 2018 (dry), 2018 (wet) followed by 2019 (dry) and lastly 2019 (wet).

\section{CONCLUSION}

The main conclusions of this study can be summarised as:

1. The values of (IWQI) were higher in the wet season than in the dry season, since the dry season results in a decline in the discharge of the Hilla River and its branches, which provides fresh water to the region's wells.

2. The spatial distribution shows that there is a slight variation of $\mathrm{pH}$ values with an irregular change in the values of (SAR) for all wells and for the years of study in its dry and wet seasons.

3. High (EC) and (TDS) levels in groundwater suggest high salinity, which is caused by soil leaching. It is hard to use for direct irrigation. The spatial distribution of EC and TDS is high in the eastern and western parts of the area map, but low in the central western parts.

4. For the positive ions, $65 \%, 100 \%, 90 \%$, and $60 \%$ of observed values $\mathrm{K}^{2+}, \mathrm{Na}^{+}$, $\mathrm{Mg}^{2+}$ and $\mathrm{Ca}^{2+}$, respectively, were higher than the permissible limits. The spatial distribution on the map is high in the southeastern and northwestern part and low in the eastern and northern part. As for the negative ions, $100 \%, 75 \%$, and $97 \%$ of the values for $\mathrm{Cl}^{-}, \mathrm{SO}_{4}{ }^{2-}$, and $\mathrm{HCO}_{3}{ }^{-}$, respectively, were also higher than the 
permissible limits. The spatial distribution on the map is high in the southern part as well as the part Western and low in the northern part.

5. The SAR values do not cause significant problems in filtering the main components into the soil. (85\%) of (SAR) values between (3-6) and (EC) values greater than $(1200 \mu \mathrm{s} / \mathrm{cm}) .15 \%$ of the SAR values between (0-3) where EC are greater than $(700 \mu \mathrm{s} / \mathrm{cm})$. The spatial distribution of SAR values is random on the map, depending on the change in sodium concentrations.

6. For dry and wet seasons, a large percentage of wells have poor water quality and need relatively high permeability soils and salt-resistant plants.

\section{ACKNOWLEDGEMENTS}

The authors thank for Al-Qasim Green University (collage of water resources engineering) and Ministry of Higher Education, Iraq for support this research.

\section{REFERENCES}

Abbasnia, A., Radfard, M., Mahvi, A. H., Nabizadeh, R., Yousefi, M., Soleimani, H., \& Alimohammadi, M. (2018). Groundwater quality assessment for irrigation purposes based on irrigation water quality index and its zoning with GIS in the villages of Chabahar, Sistan and Baluchistan, Iran. Data in Brief, 19, 623631. https://doi.org/10.1016/j.dib.2018.05.061"

Abdullah, T., Salahalddin, A., \& Al-Ansari, N. (2015). Effect of agricultural activities on groundwater vulnerability: Case study of Halabja Saidsadiq Basin, Iraq. Journal of Environmental Hydrology, 23(10).'

Al-Amar, H. A. (2015) The quality of ground water for selected area in south of Babylon Governorate/Iraq. IOSR Journal of Applied Geology and Geophysics, 3(4), 29-36. https://doi.org/10.9790/0990-03412936

Al-Dabbas, M. A., \& Al-Ali, E. A. (2016). Computation of climatic water balance for greater Musaiyab project site in Babylon Governorate-Central of Iraq. Iraqi Journal of Science, 57(2C), 1445-1451.

Al-Khaqani, M. (2006). Study the phenomenon of swelling clay soils in the city of Hillah(Unpublished Master's thesis). College of Science, University of Baghdad, Iraq.

Al-Mohammed, F. M., \& Mutasher, A. A. (2013). Application of water quality index for evaluation of groundwater quality for drinking purpose in dibdiba aquifer, Kerbala city, Iraq. Journal of University of Babylon, 21(5), 1647-1660.

Al-Qawati, M., El-Qaysy, M., Darwesh, N., Sibbari, M., Hamdaoui, F., Kherrati, I., El Kharrim, K., \& Belghyti, D. (2018). Hydrogeochemical study of groundwater quality in the west of Sidi Allal Tazi, Gharb area, Morocco. Journal of Materials and Environmental Sciences, 9(1), 293-304. https://doi.org/10.26872/ jmes.2018.9.1.33

Al-Ridah, Z. A., Al-Zubaidi, H. A. M., Naje, A. S., \& Ali, I. M. (2020). Drinking water quality assessment by using water quality index (WQI) for Hillah River, Iraq. Ecology, Environment and Conservation Paper, 26(1), 390-399. 
Al-Zubaydi, J. H., Al-Kaildy, A. A., \& Al-Rubaey, M. Q. (2016). Engineering properties of soft clay stabilized with lime materials, emulsified asphalt and bentonite sodium for sub grade of road under construction in Hilla city-Babylon governorate. International Journal of Civil Engineering and Technology, 7(5), 347-367.

Ayers, R. S., \& Westcot, D. W. (1985). Water quality for agriculture (Vol. 29). Food and Agriculture Organization of the United Nations.'

Ayers, R. S., \& Westcot, D. W. (1999). The water quality in agriculture. UFPB.

Basha, A. A., Durrani, M. I., \& Paracha, P. I. (2010). Chemical characteristics of drinking water of Peshawar. Pakistan Journal of Nutrition, 9(10), 1017-1027. https://doi.org/10.3923/pjn.2010.1017.1027

Bernardo, S. (1995). Manual of irrigation (4th Ed.). UFV.

Bhat, M. A., Wani, S. A., Singh, V. K., Sahoo, J., Tomar, D., \& Sanswal, R. (2018). An overview of the assessment of groundwater quality for irrigation. Journal of Agricultural Science and Food Research, 9(1), Article 1000209.

Boateng, T. K., Opoku, F., Acquaah, S. O., \& Akoto, O. (2016). Groundwater quality assessment using statistical approach and water quality index in Ejisu-Juaben Municipality, Ghana. Environmental Earth Sciences, 75(6), Article 489.' https://doi.org/10.1007/s12665-015-5105-0

Chabuk, A., Al-Ansari, N., Hussein, M. H., Kamaleddin, S., Knutsson, S., Pusch, R., \& Laue, J. (2017). Soil characteristics in selected landfill sites in the Babylon Governorate, Iraq. Journal of Civil Engineering and Architecture 11, 348-363. https://doi.org/10.17265/1934-7359/2017.04.005

Deshmukh, K. K. (2013). Impact of human activities on the quality of groundwater from Sangamner Area, Ahmednagar District, Maharashtra, India. International Research Journal of Environment Sciences, 2(8), 66-74.

Gidey, A. (2018). Geospatial distribution modeling and determining suitability of groundwater quality for irrigation purpose using geospatial methods and water quality index (WQI) in Northern Ethiopia. Applied Water Science, 8, Article 82. https://doi.org/10.1007/s13201-018-0722-x

Hassan, T., Parveen, S., Bhat, B. N., \& Ahmad, U. (2017). Seasonal variations in water quality parameters of River Yamuna, India. International Journal of Current Microbiology and Applied Sciences, 6(5), 694-712. https://doi.org/10.20546/ijcmas.2017.605.079

Holanda, J. S., \& Amorim, J. A. (1997). Management and control salinity and irrigated agriculture water. Congresso Brasileiro de Engenharia setting, 26, 137-169.| http://dx.doi.org/10.18535/ijetst/v3i09.10

Jain, C. K., Sharma, M. K., \& Omkar, K. (1997). Ground water quality variation in district Jammu. Indian Journal Of Environmental Protection, 17(6), 401-405.

Kushwah, R. K., Malik, S., Majumdar, K., \& Bajpai, A. (2012). Wastewater quality studies of inlet and outlet at municipal wastewater treatment plant at Bhopal, India. International Journal of Chemical Sciences, 10(2), 993-1000.

Lateef, K. H. (2011). Evaluation of ground water quality for drinking purpose for Tikrit and Samarra cities using water quality index. European Journal of Scientific Research, 58(4), 472-481. 
Mahmood, A. A., Eassa, A. M., Muayad, H. M., \& Israa, Y. S. (2013). Assessment of ground water quality at Basrah, Iraq by water quality index (WQI). Journal of University of Babylon, 21(7), 2531-2543.

Majeed, S. A. A. D., Mohammed, O. I., \& Hassan, W. H. (2016, December 27-29). Determining irrigation water quality index for evaluation groundwater quality of Green-Belt Zone, Karbala, Iraq.) In 4th International Congress on Civil Engineering, Architecture and Urban Development (pp. 1-12). Shahid Beheshti University, Tehran, Iran.

Mallick, J. (2017). Hydrogeochemical characteristics and assessment of water quality in the Al-Saad Lake, Abha Saudi Arabia. Applied Water Science, 7(6), 2869-2882. https://doi.org/10.1007/s13201-017-0553-1

Meireles, A., Andrade, E. M., Chaves, L., Frischkorn, H., \& Crisostomo, L. A., (2010). A new proposal of the classification of irrigation water. Revista Ciencia Agronomica, 413, 349-357. http://dx.doi.org/10.1590/ S1806-66902010000300005

Ravikumar, P., \& Somashekar, R. K. (2015). Principal component analysis and hydrochemical facies characterization to evaluate groundwater quality in Varahi river basin, Karnataka state, India. Applied Water Science, 7(2), 745-755. https://doi.org/10.1007/s13201-015-0287-x

Salama, R. B., Otto, C. J., \& Fitzpatrick, R. W. (1999). Contributions of groundwater conditions to soil and water salinization. Hydrogeology Journal, 7, 46-64. https://doi.org/10.1007/s100400050179

Singh, C. K., Kumari, R., Singh, N., Mallick, J., \& Mukherjee, S. (2012). Fluoride enrichment in aquifers of the Thar desert: Controlling factors and its geochemical modelling. Hydrological Processes, 27(17), 2462-2474. https://doi.org/10.1002/hyp.9247

Sravanthi, K., \& Sudarshan, V. (1998). Geochemistry of groundwater, Nacharam Industrial area, Ranga Reddy district, A.P. India. Journal of Environmental Geochemistry, 1(2), 81-88. https://doi.org/10.1007/ s13201-016-0441-0 
